\title{
Overview of the Special Issue
}

\section{"Liquefaction Phenomena in the Downstream Basin of the Tone River, Eastern Kanto Region, Japan} from the Viewpoint of Earth Science:
Geological and Geo-historical Features of Liquefied Sites"

\author{
Hiroshi UNE*, Taku KOMATSUBARA**, Takayuki NAKANO*, \\ Tomonori NAYA** and Yoshinori MIYACHI**
}

\section{Purpose of this special issue}

This special issue, "Liquefaction Phenomena in the Downstream Basin of the Tone River, Eastern Kanto Region, Japan from the Viewpoint of Earth Science: Geological and Geo-historical Features of Liquefied Sites," is a collaboration based on geomorphological, geological, and geophysical research results obtained for liquefaction phenomena caused by the 2011 off the Pacific coast of the Tohoku Earthquake.

This earthquake induced many geologic convulsions over the wide area in the eastern part of Japan. Major liquefaction events occurred in the Kanto district, and were much more extensive than in the Tohoku district, which was nearer the epicenter than the Kanto district, causing severe damage (e.g., Wakamatsu and Senna, 2015). As is generally known, geotechnical researchers and other specialists have undertaken intensive research to reveal the nature of liquefaction. Also, earth scientists, such as geomorphologists, quaternary geologists, geophysical exploration researchers, landhistory researchers, and physicists in earth science institutes including the National Institute of Advanced Industrial Science and Technology, the Geospatial Information Authority of Japan, Niigata University, and the Research Institute of Environmental Geology etc. deployed various investigations from the viewpoint of earth science.

Earth scientists are familiar with comprehensively understanding of earth-surface condition not as a set of points, but as phenomena with two or three dimensional spread including depth information, and as historical events that change with time. The editors are confident that this earth-scientific perspective has different advantages when studying liquefaction other than geotechnical approaches, and may generate new ways of estimating potential liquefaction hazards.

The downstream basin of the Tone River was not only the area most severely affected by liquefaction due to the 2011 earthquake, but also experienced severe liquefaction induced by the 1987 off the Chiba prefecture earthquake. Therefore, liquefaction records of past earthquakes are also available for this area. Besides, this area includes various geological aspects, with a landscape ranging from coastal to inland. So, it is an important area for clarifying the nature of liquefied land.

\footnotetext{
* Geospatial Information Authority of Japan, Tsukuba, 305-0811, Japan

** National Institute of Advanced Industrial Science and Technology, Tsukuba, 305-8567, Japan
} 
The aims of this special issue are to: (1) integrate the results of individual researches by earth scientists; (2) elucidate the characteristics of liquefaction phenomena from the viewpoint of earth science; and, (3) provide basic scientific information that can contribute to reducing liquefaction damage.

\section{Outline of articles}

Five papers consisting of two sedimentologic articles by J. Komatsubara et al. and Urabe and Yamamoto, a physical geographic and geophysical explorational article by Nakano et al., an article by Aoyama and Koyama, who study geomorphology and land history, and a letter from Nakashima, a petrophysicist, are published in this issue.

Komatsubara et al. (2017) constructed a three-dimensional geological model using many existing boring logs and four stratigraphic bores. They concluded: (1) the distribution of liquefaction damage generally traces reclaimed land; (2) relatively deep structures such as at the layer of the Holocene generally disagree with the actual distribution of liquefaction; and, (3) multiple factors may have combined with the occurrence of liquefaction.

Urabe and Yamamoto (2017) carried out boring-core observations and grading analyses in the severely hit Hinode area of Itako City, Ibaraki Prefecture. They conclude: (1) liquefaction occurred in the sand layer in man-made strata caused by a sand pump system; (2) differences in damage to housing were related to thickness and grain size distribution; and, (3) a grading analysis is a high-precision technique for evaluating liquefaction risk.

Nakano et al. (2017) carried out two-dimensional electrical resistivity imaging and a ground-penetrating radar (GPR) survey across a liquefied former river channel and the unliquefied hinterland to clarify subsurface structures and hydraulic conditions. The results are as follows. (1) Two-dimensional electrical resistivity imaging could identify the paleo-river channel topography of an older period at the Tone River site and the Kinu River site; howev- er, it could not clarify liquefaction-made structures and ground water level. (2) At the Kinu River site, liquefaction damage tends to be greater as the depth of the old riverbed increases. These indicate the utility of identifying the shallow underground structure of a former river channel through geophysical exploration and the relationship between its underground structure and liquefaction risk distribution.

Aoyama and Koyama (2017) identified the locations of former sand-gravel pits using old edition maps and aerial photographs taken over time, and superimposed them on the distribution of liquefaction sites using geographic information systems. The results were: (1) liquefaction occurred in refilled sand-gravel pits, with the appearance ratio of liquefaction in refilled sites being very high; and, (2) there was no clear example of liquefaction at refilled fine soil sites. These results show that the probability of liquefaction is very high even at a sand dune where previous studies indicate that the potential for liquefaction is relatively low, under the condition of land-history, and that time-sequential land-history is important for evaluating liquefaction hazard.

Nakashima (2017) introduced an algorithm for a nondestructive analysis and three-dimensional imaging of images taken with an X-ray CT scanner, and proposed a new technology for detecting traces of liquefaction in boring cores. Because liquefaction is a reproducible phenomenon, it is promising to apply such a technique for improving evaluations of liquefaction hazard by detecting former liquefaction events.

The editors hope the papers in this special issue will contribute to a general understanding of the relations between liquefied sites and their geological and geo-historical backgrounds, and the establishment of liquefaction prediction and risk determination techniques from the viewpoint of earth science.

\section{References}

Aoyama, M. and Koyama, T. (2017): Relationship between liquefied areas caused by the 2011 off the $\mathrm{Pa}$ cific coast of Tohoku Earthquake and time-series changes in the distribution of sand-gravel pits in 
Kamisu and Kashima Cities. Journal of Geography (Chigaku Zasshi), 126, 767-784. (in Japanese with English abstract)

Komatsubara, J., Ishihara, Y., Ishihara, T., Kazaoka, O. and Mizuno, K. (2017): Relationship between liquefaction damage and structure of lithological heterogeneity of Holocene postglacial deposits in the downstream basin of the Tone River, central Japan. Journal of Geography (Chigaku Zasshi), 126, 715-730. (in Japanese with English abstract)

Nakano, T., Koarai, M., Sugai, T. and Yoshida, T. (2017): Estimating of subsurface structures around liquefied former river channels of the Tone/Kinu River with geophysical prospecting. Journal of Geography (Chigaku Zasshi), 126, 749-765. (in Japanese with English abstract)

Nakashima, Y. (2017): Introduction to GrowCut, an image segmentation algorithm applied to liquefaction images. Journal of Geography (Chigaku Zasshi), 126, 785-794. (in Japanese with English abstract)

Urabe, A. and Yamamoto, T. (2017): Relation between liquefaction damages and grain size distribution of liquefied sand caused by the 2011 off the Pacific coast of Tohoku Earthquake in the Hinode area of Itako City. Journal of Geography (Chigaku Zasshi), 126, 731-748. (in Japanese with English abstract)

Wakamatsu, K. and Senna, S. (2015): Liquefaction and their site conditions in Kanto region during the 2011 off the Pacific coast of Tohoku Earthquake. Journal of Japan Association for Earthquake Engineering, 15(2), 25-44. (in Japanese with English abstract) 